\begin{tabular}{|l|l|l|}
\hline \multicolumn{2}{|c|}{ PublisherInfo } \\
\hline \hline PublisherName & $:$ & BioMed Central \\
\hline \hline PublisherLocation & $:$ & London \\
\hline \hline PublisherImprintName & $:$ & BioMed Central \\
\hline \hline
\end{tabular}

\title{
Autoantibodies to nucleolin are detected very early in sera from MRL/lpr mice
}

\begin{tabular}{|l|l|l||}
\hline \multicolumn{2}{|c|}{ ArticleInfo } \\
\hline \hline ArticleID & $:$ & 131 \\
\hline \hline ArticleDOI & $:$ & $10.1186 /$ ar-2000-66865 \\
\hline \hline ArticleCitationID & $:$ & 66865 \\
\hline \hline ArticleSequenceNumber & $:$ & 88 \\
\hline \hline ArticleCategory & $:$ & Paper Report \\
\hline \hline ArticleFirstPage & $:$ & 1 \\
\hline \hline ArticleLastPage & $:$ & 3 \\
\hline \hline & & RegistrationDate : 2000-12-1 \\
\hline ArticleHistory & $:$ & OnlineDate \\
\hline \hline ArticleCopyright & $:$ & Current Science Ltd2000-12-1 \\
\hline \hline ArticleGrants & $:$ & \\
\hline \hline ArticleContext & $:$ & 130753311 \\
\hline \hline
\end{tabular}


Fanny Monneaux, ${ }^{\text {Affl }}$

Affl CNRS, Strasbourg

Keywords

Autoantibody, lupus mice

\section{Context}

Systemic lupus erythematosus (SLE) is characterized by the presence of high titers of autoantibodies reacting with complexes such as nucleosomes and spliceosomes. In most cases autoantibodies directed against nucleic acids (DNA or RNA), and proteins that bind to them, coexist in the serum of lupus patients, as well as in sera derived from several mouse strains that are susceptible to the development of SLE. One explanation for the diversity of the immune response observed in lupus is an 'intermolecuar epitope spreading' mechanism in which an initial response directed against one of the autoantigens spreads to other components of the complex. To identify the putative triggering antigen, the authors studied the reactivity of autoantibodies produced in the earliest phase of the disease in NZB/NZW F1 and MRL/lpr mice.

\section{Significant findings}

All mice tested produced autoantibodies reacting with at least one of four molecules migrating on SDS-PAGEat 150, 110, 75 or $55 \mathrm{kDa}$. The sera from all $10 \mathrm{MRL} / \mathrm{lpr}$ mice and from six of ten NZB/ NZW F1 mice at the age of 4-8 weeks strongly reacted with either the $150 \mathrm{kDa}$ or the $110 \mathrm{kDa}$ protein. Seven NZB/NZW F1 mice produced antibodies initially recognizing the $75 \mathrm{kDa}$ or the $55 \mathrm{kDa}$ protein. The $150 \mathrm{kDa}$ and $110 \mathrm{kDa}$ proteins bound DNA. The $110 \mathrm{kDa}$ protein was identified as nucleolin.

\section{Comments}

This study demonstrates that nucleolin is a very early target of autoantibodies produced in MRL/lpr mice. Because nucleolin binds nucleic acid and is cleaved by granzyme A, the authors propose that nucleolin could be the immunodominant molecule that breaks down self-tolerance. Starting from this protein, a larger, diversified Th response might then be generated, extending via intramolecular and 
intermolecular spreading of the $\mathrm{T}$ and $\mathrm{B}$ cell responses. However, data and/or a hypothesis to explain the nature of the other proteins $(150 \mathrm{kDa}, 75 \mathrm{kDa}$ and $55 \mathrm{kDa})$ are missing in this work. Moreover, no data are presented addressing whether there is also $\mathrm{T}$ cell responsiveness to nucleolin. Finally, nucleolin was not consistently targeted early in the observed response in NZB/NZW F1 mice.

\section{Methods}

Immunoblotting, ELISA

\section{References}

1. Hirata D, Iwamoto M, Yoshio T, Okasaki H, Masuyama J, Mimori A, Minota S: Nucleolin as the earliest target molecule of autoantibodies produced in MRL/lpr lupus-prone mice. Clin Immunol. 2000, 97: 50-58. 